\title{
Reading ability and academic acculturation: The case of South African students entering higher education
}

\author{
Tobie van Dyk \\ Centre for Academic and Professional Language Practice - School of Languages, North-West University, South \\ Africa \\ E-mail: tobie.vandyk@nwu.ac.za
}

Kris van de Poel

Department of Linguistics - Applied Language Studies, University of Antwerp, Belgium | Centre for Academic and Professional Language Practice - School of Languages, North-West University, South Africa

Email: kris.vandepoel@uantwerpen.be

Frans van der Slik

Department of Linguistics, Radboud University Nijmegen, the Netherlands | Department of Linguistics and Language Practice, University of the Free State, South Africa

E-mail: f.v.d.slik@let.ru.nl

\begin{abstract}
First-year students experience a range of challenges when transferring from secondary to higher education (HE) (cf. Darlaston-Jones et al. 2003, Leki 2006, Brinkworth et al. 2009). This is no different in South Africa, where deviating levels of preparedness for the demands of HE is a recurring theme (Slonimsky and Shalem 2005, Van Schalkwyk 2008, Scott 2009, Yeld 2009, Van Dyk 2010, Van Dyk and Coetzee-Van Rooy 2012). Weideman (2003:56) rightfully points out that the inability to understand and utilise appropriate academic discourse has a detrimental effect on academic success. Young students need to acculturate to the academic environment while adopting the academic community's currency (Van de Poel and Gasiorek 2012a:294). With this article, we wish to contribute to the discussion by reporting on the academic language ability of one group of first-year students at a South African university, with specific reference to these students' reading ability, on the basis of the following data: (i) individual differences in terms of learner characteristics (race, first language, gender, Grade 12 results, academic performance); (ii) self-reported reading preparedness; and (iii) reading profiles resulting from a valid and reliable academic literacy test, the Test of Academic Literacy Levels (TALL) and its Afrikaans counterpart, the Toets van Akademiese Geletterdheidsvlakke (TAG). The findings suggest that academic reading ability, as reflected in the test results, is indeed one of the salient contributors to academic success (as confirmed in the literature), regardless of social and individual differences, and that it needs to be supported in order for students to perceive their reading ability in accordance with their reading performance and be able to progress in their academic acculturation. A follow-up study will report on students' awareness-raising about
\end{abstract}


their own academic reading through the use of the validated scale for Perceived Academic Reading Preparedness (PARP) as a pedagogical tool.

Keywords: academic acculturation, academic literacy, academic reading, perceptions of reading ability, academic performance

\section{Introduction}

It has been reiterated in both international and local research literature that the transition from secondary to higher education (HE) is not just a change of physical environment, but also a change of culture that, in many cases, may result in a high drop-out rate, particularly during the first year of study (cf. Brinkworth et al. 2009; Darlaston-Jones et al. 2003; Foxcroft and Stumpf 2005; Kuh et al. 2007; Scott 2009; Scott, Yeld and Hendry 2007; Slonimsky and Shalem 2005; Van de Poel and Gasiorek 2012a, 2012b; Van Dyk 2010; Van Dyk and Coetzee-Van Rooy 2012; Van Schalkwyk 2008; Yeld 2009). Moreover, it is widely accepted that the academic performance and motivation of first-year students to stay in HE depend, amongst others, on how well they integrate into the university environment (Brinkworth et al. 2009:168). Integration, within the scope of this article, is defined as the ability (and motivation) of students to negotiate, assimilate, understand, embrace, interact and engage with academic discourse in all its diversity, which - in turn - relies on Hyland's (2009:1) definition of academic discourse as "the ways of thinking and using language which exist in the academy". Weideman (2003:56) rightfully points out that an inability to understand and utilise the appropriate academic discourse is one of the major causes of academic failure. Students, in other words, have to conform to the academic community's communicative currency: the norms, standards, procedures and linguistic forms that constitute academic discourse (cf. Duff 2010; Hyland 2009; Gee 1998, 2000; Van de Poel and Gasiorek 2012a:294). When students are adequately literate, they will be able to activate the knowledge and skills required to communicate and function in the academic environment and become acculturated and potentially successful.

\section{A South African perspective}

The preparedness levels of first-time students in South African HE have been questioned before (Foxcroft and Stumpf 2005, Van Dyk 2010, Van Dyk and Coetzee-Van Rooy 2012, Van Schalkwyk 2008, Yeld 2001). Investigations into possible explanations for low pass rates have revealed so far that, firstly, the legacy of socio-economic and political factors rooted in the educational policies of the past still remains (Cooper and Van Dyk 2003:68) and that quality teaching and learning is to a large extent still elusive (De Bot 2005:9-10); secondly, that the ongoing debate on mother-tongue education, bilingualism and multilingualism has so far not led to an effective policy (Alexander 2005; Alexander and Bloch 2004; Altbach and Knight 2007:297; Banda 2009:5-6; Bloch 2006; Coetzee-Van Rooy 2010:19; Deyi et al. 2007; Henning et al. 2001; Henning and Van Rensburg 2002; Heugh 2000:5-6; Van der Walt 2004, 2010); thirdly, that due to the massification of HE many school-leavers end up in academic education instead of in vocational training (Scott 2009:25), and lastly, that "the education system at all levels needs well-planned and well-implemented interventions" in order to improve (Van Dyk and Coetzee-Van Rooy 2012:7).

The linguistic arguments for low pass rates usually include references to low levels of competency in the language(s) of teaching and learning as well as the fact that the language 
curriculum in secondary education does not necessarily equip prospective students adequately with the higher-order language-thinking skills they need (cf. Blacquiére 1989, Leibowitz 2001, Macdonald 1990, Perkins 1991, Pretorius 1995, Van Rensburg and Weideman 2002, Vorster and Reagan 1990). Van Dyk et al. (2007:155-156) investigated the low levels of proficiency in the languages of teaching and learning and ascertained that first-year students find it difficult to listen effectively to lecture content where they sometimes need to listen extensively and at other times intensively. Next, the researchers observed that students also experience difficulty in voicing logical arguments about course or lecture content. In addition, they noted that students do not have a sound academic approach towards academic texts, class tasks or test questions that are characterised by sophisticated argument structure or abstract scientific content. Finally, students seem to struggle to adhere to basic requirements for the completion of academic tasks. These observations, amongst others, were confirmed by the academic literacy tests administered annually to first-year students at a national level (Van Dyk 2010, Yeld 2009) and the performance of South African learners in a variety of international literacy and numeracy tests (cf. results in the 2006 Progress in Reading Literacy Study [PIRLS] reported in Mullis et al. 2007, and results report in the 2007 Trends in International Mathematics and Science Study [TIMMS] reported in Mullis et al. 2008).

\section{Academic literacy and reading}

The fact that newcomers struggle to integrate and succeed in an academic context, possibly because they experience academic literacy deficiencies, is a universal phenomenon (DarlastonJones et al. 2003, Leki 2006, Brinkworth et al. 2009). The skill that has been most heavily focused upon in this context is writing, and an often-heard complaint from faculty is "My students can't write!" (Van de Poel and Brunfaut 2004). Remedial writing research over the past twenty years (conducted by, amongst others, leading figures like Johns, Lea and Street) has taken first a product and later a process approach, embracing skills training, socialisation and empowerment. Since the proposed teaching and learning solutions have not all proven equally effective, and the pendulum has swung from product- to process-focus and back again, the scope has been widened to look into reading deficiencies as playing a foundational role in academic writing and academic success. After all, students are expected to fulfil fundamental reading requirements (reading-to-learn). Since reading is generally regarded as a more "basic" skill on which other skills rely heavily, and since academic reading skills are often taken as a given, attention so far has often been focused on learning-to-read. This does not suffice, as indicated by Dreyer and Nel (2003:349) and supported by research undertaken by Brunfaut (2008), since "[o]ne of the most serious problems in higher education, but one which is often not recognized by either students or lecturers until some way into academic courses, is the problem of reading, perhaps because reading per se is not assessed. However, the results or outputs from reading are assessed". Pretorius (2002:172) contended that the high failure rate among school-leavers can, inter alia, be ascribed to struggling with reading-to-learn. On the basis of statistics from different South African case studies on the reading ability of university students, she concluded that "[o]verall, the reading situation within the South African educational context appears to be a fairly dismal one" (Pretorius 2002:174). A decade later, the same author maintains that reading ability of learners across the board is still considered to be inadequate, and she emphasises that literacy inequalities should be addressed already at primary school level (Pretorius 2012:75). This is, however, easier said than done, as "[1]iteracy inequalities abound on the African continent and in our own education system with its many disadvantaged schools. [...] Poverty, poor schooling, low literacy levels and unemployment tend 
to go hand in hand" (Pretorius 2012:75). She continues by saying that if reading development is addressed actively and in an accountable manner in primary school, it will enhance learners' academic literacy levels to such an extent that they are not susceptible to academic failure at a later stage in their lives.

In a pedagogical framework, students play a vital role. Recent international case studies revealed, for example, that first-year students overall score high on self-efficacy (De Geest 2012, Van de Poel and Gasiorek 2012b). Only after receiving their first grades, the students' positive self-image decreases and they become more realistic (in the eyes of their tutors) and critical about their abilities and more willing to change and adapt their learning strategies and accommodate to the academic community. In South Africa, Ochse (2005) investigated students' overestimation of their academic abilities. This corresponds to the findings by Coetzee-Van Rooy (2011) who discovered a discrepancy between students' perceptions of their English proficiency (including their reading ability) and the scores obtained on English tests.

\section{Aim of the study}

Inspired by the abovementioned findings, the purpose of this article is to contribute to the discussion by providing empirical evidence of the relationship between the (perceived) reading ability and the academic performance of South African university students. In this exploratory study, we will report on the academic language ability of a group of first-year students on the basis of the following data: (i) individual differences in terms of learner characteristics (race, first language, gender, Grade 12 results, academic performance); (ii) self-reported reading requirements, preparedness and needs; and (iii) reading profiles resulting from a valid and reliable academic literacy test, the Test of Academic Literacy Levels (TALL) and its Afrikaans counterpart, the Toets van Akademiese Geletterdheidsvlakke (TAG).

\section{Research design}

\subsection{Instruments used}

The design for this study is exploratory and longitudinal in nature and the study took place at a South African university in 2011. A questionnaire was designed to investigate, amongst others, (first-year) students' academic preparedness, specifically with respect to reading. All undergraduate students were invited to complete this questionnaire. First-year students completed the questionnaire shortly after sitting the TALL and TAG academic literacy tests, which are obligatory for all students entering this university for the first time and which were, at the time, part of the entrance requirements of this particular university. The outcome of the literacy tests and the answers provided on the questionnaire were linked to the students' average Grade 12 results (end of secondary school) as well as to their weighted academic performance at the end of their first year of study. These datasets were then compared with the profiles of regular undergraduates (no longer first-year students) who completed the TALL and TAG when they were first-year students and their weighted average performance in 2011, i.e. performance on second-, third- or fourth-year level. Note that for this second group there was a lapse of time between writing TALL and TAG and completing the academic-preparedness questionnaire. The combination of different datasets proved to be rather unique and also provided distinctive insights in terms of the maturity levels of students at different stages of their studies. 
The questionnaire and tests used for this study can be characterised in more detail as follows:

The questionnaire gauging perceived academic preparedness is bilingual and contains two sections covering 22 questions in all: section one generates biographical data (14 questions with sub-questions (Q1-14)) and section two focuses on academic literacy (8 questions with subquestions (Q15-22)). The questions include Likert-scale questions (graded), yes/no questions, order-of-importance questions, tick-the-box questions, and open-ended questions.

Before administering the questionnaire, it was piloted on both subject experts (professionals in the fields of academic literacy, linguistics, education, psychology, information and computer literacy, and statistics) as well as laypeople (people not familiar with the academic environment or the fields of study mentioned above) to determine its content validity (in the case of the former group) and its face validity (in the case of the latter group).

For the present study, we will focus on one question from the second section defining academic literacy, i.e. question 17 which originally consisted of 24 sub-questions, 10 of which were isolated for the present study (see below). In the rest of the text, we will refer to these questions as studying Perceived Academic Reading Preparedness (PARP). They cover elements of reading speed, reading comprehension, analytic reading, discourse reading (coherence, cohesion and synthesising), reading strategy (planning for reading and reading techniques), and subject-specific reading (terminology).

17.In die vorige vraag was die fokus op vermoëns wat belangrik is vir akademiese sukses. In hierdie vraag is die fokus op hoe goed jy meen jy voorbereid is vir studies aan 'n universiteit. Beoordeel jou voorbereidheid op 'n skaal van 1 tot 5 (1 = glad nie voorbereid nie en 5 = baie goed voorbereid):

In the previous question the focus was on the importance of abilities that contribute to academic success. In this question the focus is on how well you believe you are prepared for studies at a university. Rate your preparedness on a scale of 1 to $5(1=$ not prepared at all and 5 = very well prepared):

\begin{tabular}{|c|c|c|c|c|c|}
\hline $\begin{array}{l}\text { My studies, tot dusver, het my voorberei om ... I } \\
\text { My studies, thus far, have prepared me to ... }\end{array}$ & 1 & 2 & 3 & 4 & 5 \\
\hline teen 'n gepaste spoed te kan lees / read at an appropriate speed & & & & & \\
\hline $\begin{array}{l}\text { voorgeskrewe leeswerk te verstaan / comprehend assigned } \\
\text { reading }\end{array}$ & & & & & \\
\hline voorgeskrewe leeswerk te ontleed / analyse assigned reading & & & & & \\
\hline $\begin{array}{l}\text { die doel van voorgeskrewe leeswerk te bepaal en dit dan te beplan } \\
\text { / determine the goal of, and then plan assigned reading }\end{array}$ & & & & & \\
\hline $\begin{array}{l}\text { voorgeskrewe lees- en skryfwerk met mekaar te sintetiseer / } \\
\text { synthesise assigned reading and writing with one another }\end{array}$ & & & & & \\
\hline $\begin{array}{l}\text { vakterminologie te internaliseer (dit vir jouself verstaanbaar te } \\
\text { maak) en dit dan toe te pas / internalise (make it comprehensible } \\
\text { to yourself) and then apply subject-specific terminology }\end{array}$ & & & & & \\
\hline $\begin{array}{l}\text { 'n hoofpunt of stelling te ontwikkel / develop a main point or } \\
\text { thesis }\end{array}$ & & & & & \\
\hline
\end{tabular}




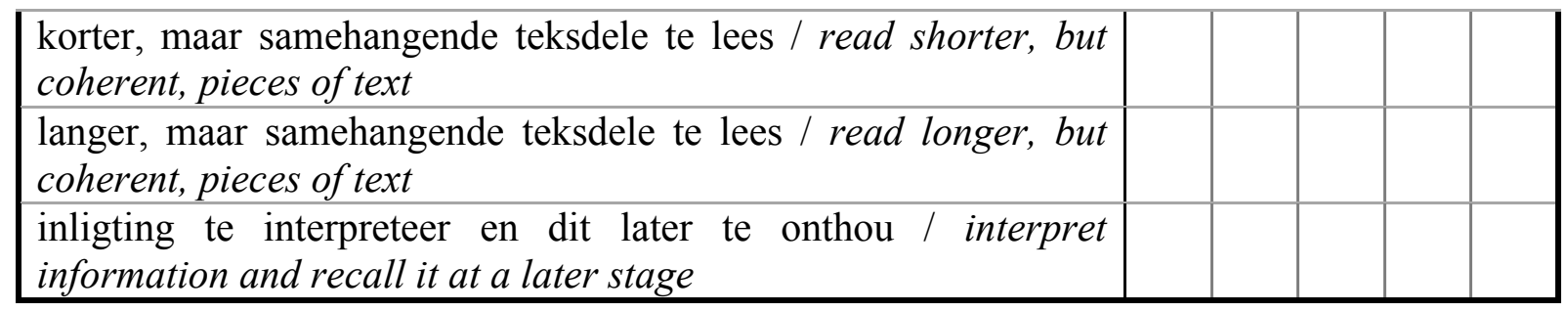

The second instrument, the TALL/TAG academic literacy tests, is valid, reliable and standardised (cf. Van Dyk and Weideman 2004 for a discussion of the construct, and Van Dyk 2010 for a discussion on reliability and validity). The test results are an indication of the risk level of every individual on a scale of 1 to 5, ranging from an "extremely high risk" (Level 1) to a "low to no risk" (Level 5) with respect to being successful at university in terms of the construct of TALL and TAG. The tests mirror each other and consist of six sections: (i) Scrambled text; (ii) Interpretation of graphic and visual information; (iii) Academic vocabulary; (iv) Reading comprehension; (v) Text type/Genre/Style; and (vi) Grammar and text relations. Each of these sections provides insight into the reading ability of students, whether in a more discrete or a more integrative manner. The respective tests consist of around 65 questions. They take an hour each to complete and include multiple-choice format questions only. The average reliability measure across 12 different administrations is 0.91 (Cronbach's Alpha), which is an indication of the test's high internal consistency. For the present study, students were required to complete both the Afrikaans and the English test.

\subsection{Description of the sample}

The participants comprised a group of $(n=1,112)$ first-year $(56.0 \%)$ as well as other undergraduate students (44.0\%) from all fields of study, representing both sexes (females: 54.06\%), different racial groups ${ }^{1}$ (Black: 6.3\%; Coloured: 16.7\%; White: 77.0\%) and different mother tongues (Afrikaans: 56.8\%; English: 36.1\%; South African African Language: 4.1\%; Other Languages: $3.0 \%$ ). The languages of teaching and learning at the participating university are Afrikaans and English - the present study therefore includes first- and second-language users. All participants were informed about the purpose of the study and the fact that they could not be disadvantaged by either partaking or refusing to partake in it. All participants gave their consent to participate anonymously in the research as well as having the opportunity to withdraw at any given stage without being disadvantaged in any way.

The sample can be further described taking into account secondary school performance, perceived preparedness, academic literacy and academic performance (see summary in Table $1)$ :

\section{Secondary school performance}

Information on individual students' final school results (Grade 12) was available from the Student Information System. An analysis of the average scores disclosed scores ranging from 48.30 to 107.10 , with a mean score of $76.61(S D=11.46)$.

\footnotetext{
${ }^{1}$ Note that it is indeed the case that racial categories are nowadays contestable as social constructs, but this applies to all background characteristics. Furthermore, if one considers the fact that the South African National Government, on all levels, still gives preference to indications of race, "racial groups" might still be an acceptable term to use. However, perhaps politically correct terms like "previously disadvantaged" or "cultural orientation" could be used when referring to certain groups.
} 
Perceived preparedness: Academic reading ability

A scale was constructed based on the information provided by the participants under the 10 items gauging perceived academic reading ability in Question 17 of the questionnaire. On average, students considered themselves to be well prepared for the academic reading demands. Their perceived ability was $4.13(S D=.66)$ on a scale ranging from 1 (= not prepared at all) to 5 (= very well prepared). This scale turned out to be highly reliable (Cronbach's Alpha $=.92)$ and will hence be referred to as the "Perceived Academic Reading Preparedness" scale (PARP).

Tests of academic literacy levels

Scores on the tests of academic literacy levels ranged from 23 to 100 ( mean $=73.64, S D=$ 15.13) for the English (TALL) version of the test; scores on the Afrikaans (TAG) version of the test ranged from 0 to 98 (mean $=56.39, S D=19.69)$. The zero scores on the latter can be attributed to students who have not mastered Afrikaans, but took the test as part of the entrance requirements of the institution.

Weighted academic performance (for all undergraduate students; cohorts treated separately see Tables 2 and 3)

The variable of interest in this study was the academic performance of every participant, as measured by the weighted average score, of the curriculum for the year 2011. The average score was $54.55 \%(S D=18.61)$.

Table 1. Summary of the description of the sample

\begin{tabular}{lrrrr}
\hline & Min. & Max. & Mean & \multicolumn{1}{c}{ SD } \\
\hline Secondary school performance (Grade 12) & 48.30 & 107.10 & 76.61 & 11.46 \\
Perceived preparedness: academic reading ability & 1.00 & 5.00 & 4.13 & .66 \\
TALL & 23 & 100 & 73.64 & 15.13 \\
TAG & 0 & 98 & 56.39 & 19.69 \\
Weighted academic performance (in 2011) & .00 & 95.78 & 54.55 & 18.61 \\
Gender & 0 & 1 & .56 & .50 \\
\hline
\end{tabular}

\subsection{Data collection}

The TALL and TAG tests were written at the beginning of the academic year when it is compulsory for all first-year students to sit the tests. All tests were completed under standard testing conditions as specified in the test administration guide.

First-year students completed the PARP-questionnaire online shortly after writing the TALL and TAG, and on a voluntary basis. All other undergraduate students reflected on their PARP at a much later stage (a year, or even two, after sitting the TALL and TAG). The entire questionnaire took students, on average, 30 minutes to complete. Background information not gathered by means of the questionnaire itself was obtained from the institution's Student Information System. The questionnaire was distributed to all undergraduate students and 2,151 responses were collected in total. Of these, only 1,112 were completed in full (especially with reference to PARP) and could be used for the analyses performed for this study. 


\subsection{Analyses}

Several analyses of the data were carried out. First and foremost, the PARP-responses were validated, after which reading ability and literacy levels were correlated. Finally, regression analyses were performed to measure academic success.

\section{Construction of the scale for perceived academic reading preparedness}

As indicated above, 10 items of Question 17 were isolated and underwent Principal Component Analysis in order to check if the underlying construct of 'perceived academic reading preparedness' was one-dimensional in character. The reason for this was that we expected all items to refer to the same latent theoretical concept of PARP. Indeed, this proved to be the case, with the Eigen value of the first component being 5.45, while the remaining Eigen values were all well below unity. The explained variance of this first component was $60.72 \%$, implying that the reduction of explained variance of the nine separate items $(100 \%)$ was quite small. The reliability of the scale for PARP can thus be qualified as excellent (Cronbach's Alpha $=.92$ ). The students' mean score on the PARP-scale was $4.13(S D=.66)$, indicating that the average undergraduate student perceived his or her academic reading ability as more than satisfactory, or regarded him- or herself as "very well prepared" as indicated on the scale.

Correlations of perceived academic reading preparedness and the tests for academic literacy levels

In order to gain some insight into how students regard their preparedness for the academic reading demands associated with $\mathrm{HE}$, their scores on the PARP-scale were correlated with their TALL and TAG scores. Note again that first-year students filled in the questionnaire containing items concerning their academic reading ability shortly after they sat the academic literacy levels tests in which their academic reading was also tested. It might therefore be expected that the respondents had a relatively accurate perception of their academic reading ability (or lack thereof). Quite remarkably, this was not the case because the correlations of academic reading ability with the test for academic literacy levels turned out to be low. A correlation of only $r=$ .08 was found with the Afrikaans test (TAG), and for the English version (TALL), the association was even lower with $r=.06$. It also seems that the low-performing students, according to the academic literacy levels tests, tend to overestimate their preparedness for academic reading more than those who perform better.

\section{Regression analyses}

In order to predict the variation in academic success rates as measured by the weighted academic performance of students at the end of 2011, several hierarchical regression analyses were performed. The following independent variables were used in blocks: (1) perceived preparedness of academic reading ability; (2) TALL and TAG results; (3) gender, first language (Afrikaans, English, South African African Languages, Other languages) and race (Black, Coloured, White); and (4) secondary school performance (Grade 12).

The rationale behind this particular kind of analysis is that we wanted the independent variables, which in time are most closely connected with the outcome variable, to be included first, in order to get an indication of the strength of their direct effect, if any. Separate analyses were conducted for first-year students and the remaining undergraduate students (see Tables 2 and 3 respectively). 
In Table 2 (Block 1) it can be seen that PARP has no effect whatsoever on the academic success of first-year students. Block 2 reveals that the TALL and TAG test results might be indications of the skills being measured (insofar as the scores refer to academic skills) or, put differently, contribute to academic success in the predicted direction $(B=.27, S E=.05, p<.001$ and $B=$ $.11, p<.001$ respectively), i.e. students' scores on TAG and TALL predict academic success to some extent (for example, one score higher on TALL results, on average, in an increase of .27 on the academic-success scale). Adding background variables such as gender, first language and race $(B=3.23, p<.05)$ (see Block 3$)$ does not alter the effects of scores in the academic literacy tests in a substantive way. Finally, secondary school performance (Grade 12 results) was added in Block 4. It proved that this variable had the strongest effect (Bèta $=.33, p<.001$ ) on academic success. Other effects that remained present are those of gender, race and language. Female students score, on average, three percentage points higher on weighted academic performance than male students. In addition, Coloured students score approximately four percentage points lower than White students, and an English-speaking student scores four percentage points higher than the average Afrikaans-speaking student. Interestingly, the effect of the academic literacy test scores (TALL and TAG) seems to disappear in this block, but it should be considered that their effect can also be indirect since scores on TALL and TAG are expected to be influenced by students' scores on secondary school performance (Grade 12 results) as well.

Table 2. Regression analysis of weighted academic performance for first-year students

\begin{tabular}{|c|c|c|c|c|}
\hline \multicolumn{2}{|c|}{ Block } & \multirow{2}{*}{$\begin{array}{c}\mathbf{B} \\
52.93^{* * *}\end{array}$} & \multirow{2}{*}{$\begin{array}{r}\text { SEB } \\
4.18\end{array}$} & \multirow[t]{2}{*}{ Bèta } \\
\hline \multirow{2}{*}{1} & (Constant) & & & \\
\hline & PARP (Question 17) & 1.04 & 1.01 & .04 \\
\hline & Explained Variance & \multicolumn{3}{|c|}{$.2 \%$} \\
\hline \multirow{5}{*}{2} & (Constant) & $28.88 * * *$ & 5.20 & \\
\hline & PARP (Question 17) & .34 & .97 & .01 \\
\hline & TAG & $.11 * * *$ & .03 & .13 \\
\hline & TALL & $.27 * * *$ & .05 & .23 \\
\hline & Explained Variance & \multicolumn{3}{|c|}{$8.5 \%$} \\
\hline \multirow{11}{*}{3} & (Constant) & $29.02 * * *$ & 5.66 & \\
\hline & PARP (Question 17) & .21 & .97 & .01 \\
\hline & TAG & $.17 * * *$ & .05 & .20 \\
\hline & TALL & $.20 * * *$ & .06 & .17 \\
\hline & Female & $3.23 *$ & 1.32 & .09 \\
\hline & Coloured & $-5.42 * *$ & 1.74 & -.12 \\
\hline & Black & -2.89 & 4.86 & -.05 \\
\hline & English & 3.64 & 2.00 & .11 \\
\hline & SA African language & 7.85 & 5.55 & .10 \\
\hline & Other language & 4.22 & 4.53 & .04 \\
\hline & Explained Variance & \multicolumn{3}{|c|}{$11.7 \%$} \\
\hline \multirow{5}{*}{4} & (Constant) & -2.54 & 6.76 & \\
\hline & PARP (Question 17) & -.19 & .93 & -.01 \\
\hline & TAG & .08 & .05 & .10 \\
\hline & TALL & .07 & .06 & .05 \\
\hline & Female & $2.91 *$ & 1.26 & .09 \\
\hline
\end{tabular}




\begin{tabular}{lccc} 
Coloured & $-4.03^{*}$ & 1.67 & -.09 \\
Black & -2.95 & 4.64 & -.05 \\
English & $3.98^{*}$ & 1.91 & .12 \\
SA African language & 6.21 & 5.30 & .08 \\
Other language & 1.97 & 4.34 & .02 \\
Grade 12 performance & $.64 * * *$ & .08 & .33 \\
\hline Explained Variance & \multicolumn{3}{c}{$19.6 \%$} \\
\hline$: p<.05 ; * *: p<.01 ; * * *: p<.001$. Reference categories: Male, White, Afrikaans.
\end{tabular}

Table 3. Regression analysis of weighted academic performance for other undergraduates

\begin{tabular}{|c|c|c|c|c|}
\hline \multicolumn{2}{|c|}{ Block } & \multirow{2}{*}{$\begin{array}{c}\mathbf{B} \\
28.97 * * *\end{array}$} & \multirow{2}{*}{$\begin{array}{r}\text { SEB } \\
6.02\end{array}$} & \multirow[t]{2}{*}{ Bèta } \\
\hline & (Constant) & & & \\
\hline 1 & PARP (Question 17) & $5.33 * * *$ & 1.42 & .17 \\
\hline & Explained Variance & & $2.8 \%$ & \\
\hline \multirow{5}{*}{2} & (Constant) & $15.30^{*}$ & 6.92 & \\
\hline & PARP (Question 17) & $4.80 * * *$ & 1.41 & .15 \\
\hline & TAG & $.11^{*}$ & .05 & .10 \\
\hline & TALL & $.14^{*}$ & .06 & .11 \\
\hline & Explained Variance & & $5.9 \%$ & \\
\hline \multirow{11}{*}{3} & (Constant) & $19.77 * *$ & 7.51 & \\
\hline & PARP (Question 17) & $4.51 * *$ & 1.42 & .14 \\
\hline & TAG & .12 & .07 & .11 \\
\hline & TALL & .08 & .08 & .07 \\
\hline & Female & 1.91 & 1.80 & .05 \\
\hline & Coloured & $-7.60 * *$ & 2.69 & -.13 \\
\hline & Black & 3.91 & 7.35 & .04 \\
\hline & English & 1.09 & 2.61 & .03 \\
\hline & SA African language & -6.39 & 9.06 & -.05 \\
\hline & Other language & -2.24 & 5.61 & -.02 \\
\hline & Explained Variance & & $7.7 \%$ & \\
\hline \multirow{12}{*}{4} & (Constant) & $-27.12 * * *$ & 8.31 & \\
\hline & PARP (Question 17) & $2.96^{*}$ & 1.30 & .09 \\
\hline & TAG & -.04 & .07 & -.04 \\
\hline & TALL & -.15 & .07 & -.12 \\
\hline & Female & .90 & 1.64 & .02 \\
\hline & Coloured & $-5.15^{*}$ & 2.46 & -.09 \\
\hline & Black & 7.65 & 6.70 & .08 \\
\hline & English & 1.93 & 2.38 & .04 \\
\hline & SA African language & -5.12 & 8.25 & -.04 \\
\hline & Other language & -8.08 & 5.14 & -.07 \\
\hline & Grade 12 performance & $1.01 * * *$ & .10 & .51 \\
\hline & Explained Variance & & $23.4 \%$ & \\
\hline
\end{tabular}

In Table 3, the outcomes are presented for undergraduate students who are not in their first year of study. The most salient difference from Table 2 is that PARP remains a significant predictor 
of academic success throughout, even when Grade 12 scores are included in Block 4. Other notable differences are that the effects of the academic literacy test scores are less pronounced for this group of undergraduates than they were for the newly-arrived students (i.e. they are less predictive of their academic success scores), and that the female advantage observed for firstyear students has disappeared.

\subsection{Discussion}

A number of observations can be made on the basis of the presented data. Perhaps the most salient is that first-year students who just arrived at university, on average, have a positive perception of their academic preparedness (not reported on specifically as it falls beyond the scope of this paper), and their reading preparedness in particular. This positive attitude might help them to overcome initial challenges when entering university. In reality, however, firstyear students tend to overestimate their preparedness for academic literacy and reading in particular, and therewith their potential academic success. This tendency is even more outspoken for those who are considered to be at risk or running the risk of low academic success, given their low scores on the tests for academic literacy levels (TAG/TALL).

Even though self-perception of academic preparedness in general and academic reading ability in particular does not predict academic success for first-year students, secondary school performance (Grade 12 results) indeed does so. In our study, being female, White and Englishspeaking positively correlated with academic performance. Although it would be tempting to believe that female students outperform the others in general, female first-year students outperform the male students only slightly, but this does not hold for the other undergraduates. White students also seem to outperform the others. This should, firstly, be seen within the South African context and the political history of the country. Secondly, it is noteworthy that the effect of the apparent outperformance is very small (see Tables 2 and 3). In sum, school results, including results obtained from the TALL and TAG tests, are much more predictive of future academic performance than perceived preparedness.

With respect to the PARP-scale, three observations should be made. First and foremost, PARP is a reliable scale which entails that students are very consistent in their perceived preparedness. Next, as pointed out above, students regard themselves as being well prepared. However, the perceived preparedness hardly seems to predict academic success. So, in effect, perceived preparedness does not reflect real preparedness, an observation which has some practical pedagogical consequences (see section 5.8).

\subsection{Limitations of this study}

There are three main limitations to this study. Firstly, even though we were able to produce a reliable scale for students' perceptions of academic preparedness and success, it does only measure perceived preparedness and not actual preparedness.

The second limitation concerns the nature of the sample. The conclusions primarily apply to first-year students, as it was found that the perceived preparedness of the remainder of the undergraduate group predicted their academic performance to a certain extent, but the strength of its impact is open for interpretation, due to the fact that the effect is not strong. 
A third limitation is the size of certain sub-samples, particularly in the case of cultural group or home language. In this regard, it needs to be noted that, even though the results for the previously disadvantaged groups seem to be not entirely reliable because of sub-sample size, the samples are representative of the population studied. In follow-up research, an option could be to use stratified samples where Black and Coloured students are over-represented. Universities with larger numbers of students with neither Afrikaans nor English as home language and with fewer previously disadvantaged students may also provide interesting results in replication studies.

\subsection{Future challenges}

Despite its limitations, the PARP-scale undeniably provides useful information about the (selfreported) perceptions of newly-arrived students - the focus of this article. There is, for example, ample anecdotal evidence of students who were not convinced that their academic literacy skills were deficient (as shown in the test results) and consequently skipped remedial tuition, but ultimately had to confess in hindsight that this had been a mistake and that it had a detrimental effect on their academic performance. This is information that can now be better understood owing to the empirical evidence provided here.

The present findings and insights should be used to convey the message that universities, and teachers/tutors in particular, should help students right from the outset of their academic life to realistically interpret their perceived levels of preparedness so that they are not shocked by the challenges presented by academic discourse. They should be shown in a positive way that there is a discrepancy between their reading test scores and their self-assessment. In other words, students should be encouraged to engage with the challenges of becoming an academic communicator by negotiating between the resources at their disposal and the expectations of academia. The questionnaire in general, and the PARP-scale in particular, might be useful tools to this end and could form the basis for in-class discussions on the nature of academic discourse and the nature of communication in the academic community (this will be the topic of a followup study). By raising students' awareness of what is expected from them as members of the academic community, rules and regulations will become more transparent and students may more easily engage with academia. This will answer students' requests for better communication on academic requirements (see, amongst others, research findings reported in Van de Poel and Gasiorek 2012a and 2012b). Moreover, exercises on reading speed, reading comprehension, analytical and discourse reading strategies and subject-specific reading matter may benefit students in their academic development, as reading is considered to be one of the salient contributors to academic success. However, the effect may be more profound, provided that students are aware of their own preparedness and academic literacy profile.

On the basis of datasets such as those presented in this article, different reading preparedness profiles could be drawn up which could be linked to student success in an attempt to determine if there is a significant correlation. Findings of this kind may inform teaching and learning in general and they may, in particular, be considered as a recommendation for managers in HE to not be too complacent about single variables that contribute to academic success (e.g. final school results), but rather to gather as much data as possible to determine the academic wellbeing of their students and the support they need to achieve this. 


\section{Conclusion}

In this article, it was shown that undergraduates, and first-year students in particular, do not adequately assess their own academic competencies - as shown by their perceived academic reading preparedness - and that they struggle to comply with the academic demands associated with university study. In other words, since students' perceived academic preparedness and competencies are not an adequate reflection of their real competencies, they have not yet fully integrated into the academic community. It was stipulated that, in order to acculturate to the academic environment, students have to learn and adopt the academic community's currency, defined as the norms, standards, procedures and linguistic forms that constitute academic discourse. This study has shown that, regardless of social and individual differences, students need support in their acculturation process. We believe that there is an important role for faculty who, first and foremost, should guide and help students to gain a more realistic perspective of the dynamics of the academic discourse community.

\section{References}

Alexander, N. 2005. After apartheid: The language question. Available online: http://www.yale-university.com/macmillan/apartheid/alexanderp2.pdf (Accessed 5 June 2013).

Alexander, N. and C. Bloch 2004. Feeling at home with literacy in the mother tongue. Unpublished keynote address at the $29^{\text {th }}$ International Board on Books for Young People (IBBY) conference, 5-8 September 2004, Cape Town.

Altbach, P.G. and J. Knight. 2007. The internationalization of higher education: Motivations and realities. Journal of Studies in International Education 11(3/4): 290-305.

Banda, F. 2009. Critical perspectives on language planning and policy in Africa: Accounting for the notion of multilingualism. Stellenbosch Papers in Linguistics (SPIL) 38: 1-11.

Blacquiére, A. 1989. Reading for survival: Text and the second language student. South African Journal for Higher Education 3(1): 73-82.

Bloch, C. 2006. Theory and strategy of early literacy in contemporary Africa with special reference to South Africa. PRAESA Occasional Papers No. 25. Cape Town: PRAESA.

Bot, M. 2005. School education in South Africa: Tracking change over ten years. EduSource Data News No. 48. Houghton: The Educational Foundation Trust. pp. 1-10.

Brinkworth, R., B. McCann, C. Matthews and K. Nordström. 2009. First year expectations and experiences: Student and teacher perspectives. Higher Education 58(2): 157-173.

Brunfaut, T.S. 2008. Foreign language reading for academic purposes. Unpublished doctoral thesis. University of Antwerp.

Coetzee-Van Rooy, A.S. 2010. The importance of multilingualism. Unpublished inaugural lecture at the North-West University, Vaal Triangle Campus, 3 September 2010. 
Coetzee-Van Rooy, A.S. 2011. Discrepancies between perceptions of English proficiency and scores on English tests: Implications for teaching English in South Africa. Journal for Language Teaching 45(2): 151-181.

Cooper, T. and T. Van Dyk. 2003. Vocabulary assessment: A look at different methods of vocabulary testing. Perspectives in Education 21(1): 67-79.

Darlaston-Jones, D., L. Pike, L. Cohen, A. Young, S. Haunold and N. Drew. 2003. Are they being served? Student expectations of higher education. Issues in Education Research 13(1): $31-52$.

De Geest, A. 2012. Freshman year: A discrepancy between social and academic well-being. Papers selected from the Junior Research Meeting. Duisburg: Universitätsverlag Rhein-Rhur. 167-176.

Deyi, S., E. Simon, S. Ngcobo and A. Thole. 2007. Promoting the multilingual classroom: Why the significance of multilingualism in higher education? Paper presented at the National Foundation Conference, 2-3 October 2011, Granger Bay. Available online:

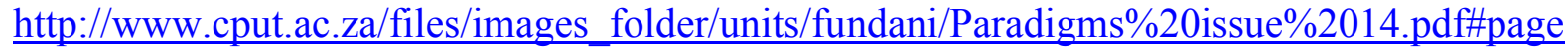
$=10$ (Accessed 10 June 2013).

Dreyer, C. and C. Nel. 2003. Teaching reading strategies and reading comprehension within a technology-enhanced learning environment. System 31(3): 349-365.

Duff, P.A. 2010. Language socialisation into academic discourse communities. Annual Review of Applied Linguistics 30: 169-192.

Foxcroft, C.D. and R. Stumpf. 2005. What is matric for? Paper presented at Umalusi and CHET seminar on "Matric: What is to be done?", 23 June 2005, Pretoria.

Gee, J.P. 1998. What is literacy? In V. Zamel and R. Spack (eds.) Negotiating academic literacies: teaching and learning across languages and cultures. Mahwah, NJ: Lawrence Erlbaum. pp.51-59.

Gee, J.P. 2000. The new literacy studies. From "socially situated" to the work of the social. In D. Barton, M. Hamilton and R. Ivanic (eds.) Situated literacies: Reading and writing in context. London: Routledge. pp. 180-196.

Henning, E., A. Mamiane and M. Pheme. 2001. Entering the academy as "the other" - about writing competence and the bridge to the discourse community. South African Journal of Higher Education 15(1): 109-128.

Henning, E. and W. Van Rensburg. 2002. Academic development in writing composition: Beyond the limitations of a functionalist and pragmatic curriculum. Journal for Language Teaching 36(1\&2): 82-90.

Heugh, K. 2000. The case against bilingual and multilingual education in South Africa. PRAESA Occasional Papers No. 6. Cape Town: PRAESA. 
Hyland, K. 2009. Academic discourse: English in a global context. London: Continuum.

Kuh, G.D., J. Kinzie, J.A. Buckley, B.K. Bridges and J.C. Hayek. 2007. Piecing together the student success puzzle: Research, propositions and recommendations. ASHE Higher Education Report Series 32(5). San Francisco: Jossey Bass.

Leibowitz, B. 2001. Students' prior learning and their acquisition of academic literacy at a multilingual South African university. Unpublished doctoral thesis. University of Sheffield.

Leki, I. 2006. Negotiating socioacademic relations: English learners' reception by and reaction to college faculty. Journal of English for Academic Purposes 5(2): 136-152.

Macdonald, C.A. 1990. Crossing the threshold into standard three in black education: The consolidated main report of the Threshold Project. Pretoria: Human Sciences Research Council.

Mullis, I.V.S., M.O. Martin and P. Foy (with J.F. Olson, C. Preuschoff, E. Erberber, A. Arora and J. Galia). 2008. TIMSS 2007 international mathematics report: Findings from IEA's Trends in International Mathematics and Science Study at the fourth and eighth grades. Chestnut Hill, MA: TIMSS \& PIRLS International Study Center, Boston College.

Mullis, I.V.S., M.O. Martin, A.M. Kennedy and P. Foy. 2007. PIRLS 2006 international report: IEA's Progress in International Reading Literacy Study in primary Schools in 40 countries. Boston: Boston College.

Ochse, C. 2005. Race differences in academic expectations and perceptions of ability in relation to actual achievement. South African Journal of Higher Education 19(2): 334-344.

Perkins, D.M. 1991. Improvement of reading and vocabulary skills at the University of Transkei. South African Journal of Education 11(4): 231-235.

Pretorius, E.J. 1995. Reading as an interactive process: Implications for studying through the medium of a second language. Communicatio 21(2): 33-43.

Pretorius, E.J. 2002. Reading ability and academic performance in South Africa: Are we fiddling while Rome is burning? Language Matters: Studies in the Languages of Africa 33(1): 169-196.

Pretorius, E.J. 2012. Butterfly effects in reading? The relationship between decoding and comprehension in Grade 6 high poverty schools. Journal for Language Teaching 46(2): 74-95.

Scott, I. 2009. First-year experiences as terrain of failure or platform for development? Critical choices for higher education. In B. Leibowitz, A. Van der Merwe and S. Van Schalkwyk (eds.) Focus on first-year success: Perspectives emerging from South Africa and beyond. Stellenbosch: SUN MeDIA. pp. 17-35. 
Scott, I., N. Yeld and J. Hendry. 2007. A case for improving teaching and learning in South African higher education. Higher Education Monitor No. 6. Pretoria: Council on Higher Education. Available online: http://www.che.ac.za/documents/d000155/index.php (Accessed 17 September 2009).

Slonimsky, L. and Y. Shalem. 2005. Pedagogic responsiveness for academic depth. Journal of Education (40): 35-58.

Van de Poel, K. and T. Brunfaut. 2004. Bridging the gap between staff expectations and student interpretations of academic writing. Belgian Journal of English Language and Literatures 2: 329-335.

Van de Poel, K. and J. Gasiorek. 2012a. Effects of an efficacy-focused approach to academic writing on students' perceptions of themselves as writers. Journal of English for Academic Purposes 11(4): 294-303.

Van de Poel, K. and J. Gasiorek. 2012b. Academic acculturation: The case of writing in an EFL teaching and learning environment. Journal of Language Teaching 46(2): 58-72.

Van der Walt, C. 2004. The challenge of multilingualism: In response to the language policy for higher education. South African Journal of Higher Education 18(1): 140-152.

Van der Walt, C. 2010. The context of language planning in multilingual higher education. Language Learning Journal 38(3): 253-271.

Van Dyk, T.J. 2010. Konstitutiewe voorwaardes vir die ontwerp van 'n toets van akademiese geletterdheid. Unpublished doctoral thesis. University of the Free State.

Van Dyk, T.J. and S. Coetzee-Van Rooy. 2012. The continual conundrum of the "language across the curriculum" issue: Lessons from the Bullock report (1975) for South African higher education today. Journal for Language Teaching 46(1): 7-29.

Van Dyk, T.J. and A.J. Weideman. 2004. Switching constructs: On the selection of an appropriate blueprint for academic literacy assessment. Journal for Language Teaching 38(1): 1-13.

Van Dyk, T.J., L. Van Dyk, H.C. Blanckenberg and J. Blanckenberg. 2007. Van bevreemdende diskoers tot toegangsportaal: e-Leer as aanvulling tot 'n akademiese geletterdheidskursus. Ensovoort 11(2): 154-172.

Van Rensburg, C. and A.J. Weideman. 2002. Language proficiency: Current strategies, future remedies. Journal for Language Teaching 36(1\&2): 152-163.

Van Schalkwyk, S.C. 2008. Acquiring academic literacy: A case of first-year extended degree programme students at Stellenbosch University. Unpublished doctoral thesis. Stellenbosch University.

Vorster, J. and T. Reagan. 1990. On the lexical development of L1 and L2 speakers. South African Journal of Linguistics 9(3): 80-84. 
Weideman, A.J. 2003. Assessing and developing academic literacy. Per Linguam 19(1\&2): 5565 .

Yeld, N. 2001. Assessment, equity and language of learning: Key issues for higher education selection in South Africa. Unpublished doctoral thesis. University of Cape Town.

Yeld, N. 2009. National benchmark tests project as a national service to higher education: Summary report June 2009. Pretoria: Higher Education South Africa. 